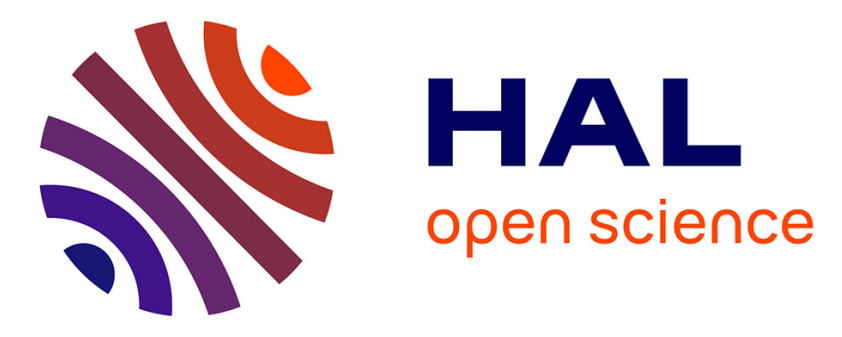

\title{
Evaluation of the anti-oxidant properties of a SOD-mimic Mn-complex in activated macrophages.
}

Anne-Sophie Bernard, Claire Giroud, H. Y. Vincent Ching, Anne Meunier, Vinita Ambike, Christian Amatore, Manon Guille Collignon, Frédéric Lemaître, Clotilde Policar

\section{To cite this version:}

Anne-Sophie Bernard, Claire Giroud, H. Y. Vincent Ching, Anne Meunier, Vinita Ambike, et al.. Evaluation of the anti-oxidant properties of a SOD-mimic Mn-complex in activated macrophages..

Dalton Transactions, 2012, 41, pp.6399-6403. 10.1039/c2dt12479c . hal-00692351

\section{HAL Id: hal-00692351 \\ https://hal.science/hal-00692351}

Submitted on 10 Apr 2020

HAL is a multi-disciplinary open access archive for the deposit and dissemination of scientific research documents, whether they are published or not. The documents may come from teaching and research institutions in France or abroad, or from public or private research centers.
L'archive ouverte pluridisciplinaire HAL, est destinée au dépôt et à la diffusion de documents scientifiques de niveau recherche, publiés ou non, émanant des établissements d'enseignement et de recherche français ou étrangers, des laboratoires publics ou privés. 


\section{Evaluation of the Anti-Oxidant Properties of a SOD-mimic Mn-Complex in Activated Macrophages}

s Anne-Sophie Bernard, ${ }^{a, b, c} c^{\#}$ Claire Giroud, ${ }^{a, b, c}{ }^{\#}$ H.Y.Vincent Ching, ${ }^{a, b, c}$ Anne Meunier, ${ }^{a, b, d}$ Vinita Ambike, ${ }^{e}$ Christian Amatore, ${ }^{* a, b, d}$ Manon Guille Collignon, ${ }^{a, b, d}$ Frédéric Lemaître ${ }^{a, b, d}$ and Clotilde Policar* ${ }^{* a, b, c}$

SOD-mimic are small complexes that reproduce the activity of superoxide dismutases, natural proteins that catalytically

10 dismutate the superoxide anion. Activated macrophages, which produce ROS and RNS fluxes, constitute a relevant model to challenge antioxidant activity in a cellular context and were used to test a Mn-complex which was shown to efficiently alter the flow of $\mathrm{O}_{2}^{-}, \mathrm{ONOO}^{-}$and $\mathrm{H}_{2} \mathrm{O}_{2}$.

15 Reactive oxygen species (ROS), such as superoxide $\left(\mathrm{O}_{2}{ }^{-}\right)$ and hydrogen peroxide $\left(\mathrm{H}_{2} \mathrm{O}_{2}\right)$, are continuously produced as byproducts of normal cellular aerobic metabolism. ${ }^{1,2}$ They are known to be part of a complex network involving also reactive nitrogen species (RNS) derived from nitric oxide (NO) as $\mathrm{O}_{2}^{-}$ 20 and $\mathrm{NO}$ can react together leading to the harmful peroxynitrite $\left(\mathrm{ONOO}^{-}\right)$(see scheme 1). Efficient protection pathways against damaging ROS have evolved and involve either low molecular weight antioxidants (E and C vitamin, GSH, etc.) or metalloenzymes (superoxide dismutases, catalases, 25 peroxidases). When these protection pathways are overwhelmed, oxidative stress arises, which occurs in a wide range of pathophysiological processes, ${ }^{2-5}$ including diabetes, inflammatory and neurodegenerative diseases, reperfusion injury after ischemia, cancer, and also aging.

30 The fact that the removal of the superoxide anion has a beneficial outcome in oxidative stress is now well documented. ${ }^{2,}{ }^{4}$ Superoxide dismutases are metalloenzymes involved in the control of the superoxide concentration inside bacteria or cells by catalytically dismutating this anion.

35 However, major drawbacks limit the therapeutic use of the enzymes (low stability, limited cellular accessibility, immunogenicity, short half-lives, cost of production, proteolytic digestion, contamination risks), ${ }^{2,} 4$ therefore low molecular-weight molecular complexes have been developed 40 as SOD-mimics, using metal ions such as copper, iron, manganese or, more rarely, cobalt ${ }^{6,7}$. In the last decade, special interest has been devoted to Mn-complexes ${ }^{2,4,5,8,9}$ as they do not lead to Fenton chemistry that induces pro-oxidant effects by the production of the reactive hydroxyl radical. Indeed, to 45 date, a large variety of Mn-derivatives have been reported for their ability to react with superoxide in non-cellular conditions (labelled herein as in vitro), either as a true SOD mimic with catalytic activity or as a stoichiometric scavenger. ${ }^{9}$ Recently, some differences have been evidenced between intrinsic SOD-

so mimic Mn-complexes' activities evaluated in vitro, and their in cellulo or in vivo efficiency, that were assigned to a differential cell-location. ${ }^{10}$ This example emphasizes the importance of testing the activity, not only in vitro, but also in biological models of oxidative stress. In vivo models range from radiation 55 injuries, ${ }^{11-13}$ chemotherapia or chemical stress, ${ }^{14,}{ }^{15}$ ischemiareperfusion injury, ${ }^{16-19}$ neuronal oxidative stress, ${ }^{20,} 21$ endotoxic shock, ${ }^{22}$ diabete, ${ }^{23}$ or inflammation. ${ }^{24}$ However, there are much less data concerning investigations on cellular models. Most of the data concern the efficiency of SOD-mimics to rescue SOD ${ }_{60}$ deficient strain of E. coli. ${ }^{10,23,25,26}$ Some other models involve other SOD deficient cells, ${ }^{10,}{ }^{27}$ cells under irradiation, ${ }^{28,} 29$ chemical stress or infection, ${ }^{14,15}$ or activated cells producing ROS species, such as macrophages ${ }^{30-33}$ or human leukemia cells. $^{34}$ 65

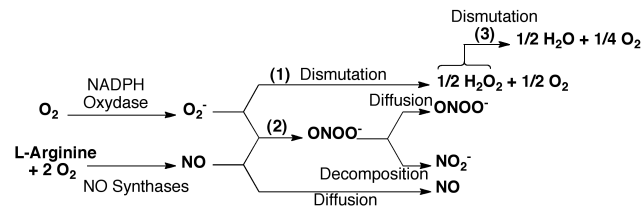

Scheme 1: Reaction scheme describing the reactive oxygen and nitrogen species in the oxidative burst of RAW 264.7 macrophages.

${ }_{70}$ Hence, there is a need for studies involving cellular models of oxidative stress to bridge the gap between in vitro and in vivo studies. We have chosen to investigate the properties of a 1,2diaminoethane based Mn(II) complex (1, see Figure 1). ${ }^{35}$ This complex, among the series of $\mathrm{N}$-centered complexes developed 75 by some of us, ${ }^{35-41}$ is of interest as it displays a good antisuperoxide activity in vitro, which is in line with its redox potential being close to that of SODs, a key parameter for the SOD-activity. ${ }^{38,} 42$ Complex $\mathbf{1}$ has been shown to have a $\mathrm{E}_{1 / 2}=0.2 \mathrm{~V} / \mathrm{SCE}(0.44 \mathrm{~V} / \mathrm{NHE}),{ }^{35}$ close to the optimal value of s0 $0.12 \mathrm{~V} / \mathrm{SCE}(0.36 \mathrm{~V} / \mathrm{NHE})^{38,42,43}$ and with $\mathrm{k}_{\mathrm{McCF}}=7.0 \pm 0.3$ $\mathrm{M}^{-1} \mathrm{~s}^{-1}, 35,44$ In this communication the activity of $\mathbf{1}$ was investigated in macrophages immuno-activated by interferon- $\gamma /$ lipopolysaccharide (IFN- $\gamma / \mathrm{LPS}$ ) and phorbol-12-myristate-13acetate (PMA), and compared with that of $\mathrm{MnCl}_{2}$. As major 85 actors in inflammation, macrophages constitute an interesting model for oxidative stress as they generate ROS and RNS high fluxes under immuno-stimulation. ${ }^{45,}{ }^{46}$ The activities of $\mathbf{1}$ and $\mathrm{MnCl}_{2}$ were first estimated on a collection of cells after incubation. To provide further in situ insights in the activity, ${ }_{90}$ experiments were conducted directly on single living cells using amperometry at ultramicroelectrodes to record real-time release of ROS and $\mathrm{RNS}^{47}$ as we and others have previously shown. ${ }^{48}$ 


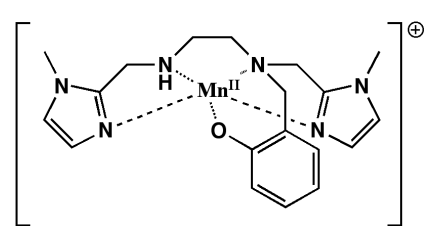

Figure 1: Schematical structure of complex 1, used as hexafluorophosphate derivative.

${ }_{5}$ Stability and cytotoxicity. The stability of the complex in cellculture medium was monitored. Using its clear signature in cyclic voltammetry, $\mathbf{1}$ was found to be stable in DMEM-culture medium (Figure S1). The cytotoxicity of $\mathbf{1}$ was then evaluated on RAW 264.7 macrophages in order to determine an

10 appropriate range of concentration to evaluate the activity of $\mathbf{1}$ on these cells. Cultures of macrophages were incubated with 2 , $5,10,20$ or $50 \mu \mathrm{M}$ of complex 1 over 24 hours. The MTT reduction assay ${ }^{49}$ showed that 1 and $10 \mu \mathrm{M}$ concentrations were suitable (see Supp. Mat., Figure S2) for the $24 \mathrm{~h}$ 15 incubation required for the IFN $\gamma /$ LPS activation.

Macrophages activation. Macrophages can be activated to produce ROS/RNS species that mostly derived from primary nitric oxide and superoxide anion. The oxidative burst is elicited through a successive IFN $\gamma /$ LPS and PMA activation

20 (see Supp. Mat.), the majority of ROS/RNS produced over IFN- $\gamma /$ LPS stimulated macrophages being due to iNOS expression, while PMA is known as a NADPH oxidase activator. $^{50-52}$

Evaluation of the SOD-activity in a cellular context using ${ }_{25}$ ferricytochrome $c$. As a first test, superoxide produced by a collection of macrophages was quantified using ferricytochrome $c$ reduction in the extracellular medium. ${ }^{53}$

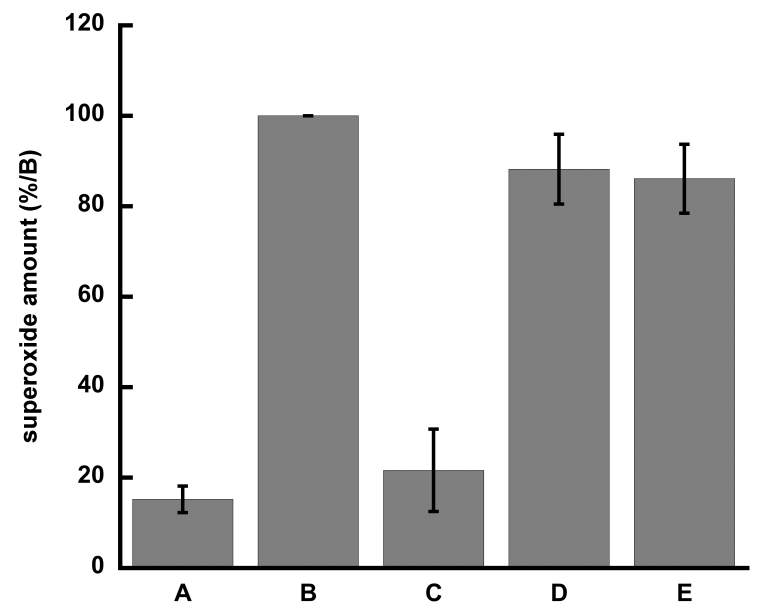

Figure 2. Mean extracellular superoxide amount for $n=6$ independent 30 experiments under several conditions: control (A), IFN $\gamma /$ LPS/PMA (B), IFN $\gamma / \mathrm{LPS} / \mathrm{PMA}+110 \mu \mathrm{M}$ (C), IFN $\gamma / \mathrm{LPS} / \mathrm{PMA}+\mathrm{MnCl}_{2} 10 \mu \mathrm{M}$ (D), IFN $\gamma / \mathrm{LPS} / \mathrm{PMA}+$ SOD $100 \mathrm{U} / \mathrm{mL}$ (E). Error bars represent SEM. This experiment reveals the intracellular activity of $\mathbf{1}$ (see text).

${ }_{35}$ Cells were incubated for $24 \mathrm{~h}$ with IFN $\gamma / \mathrm{LPS}$ and without or with $1, \mathrm{MnCl}_{2}(10 \mu \mathrm{M})$ or bovine CuZnSOD $(100 \mathrm{U} / \mathrm{mL})$. It should be noted that this protein is not able to cross membranes. ${ }^{2}$ The supernatants were then removed and a solution containing ferricytochrome $c(100 \mu \mathrm{M})$ and PMA was 40 added. After 1h, absorbance of the supernatants was measured at $550 \mathrm{~nm}^{31}$ As shown in figure 2, the amount of extracellular superoxide detected by reduction of the ferricytochrome $c$ was significantly reduced for the cells pre-treated with $\mathbf{1}$ and activated (C) in comparison with activated cells (B), the level 45 of superoxide in $\mathrm{C}$ being close to that of unactivated cells (A). No effect was recorded in the case of cells pre-treated with $\mathrm{MnCl}_{2}$ (D) or CuZnSOD (E). The absence of effect of CuZnSOD is in line with the absence of any cell-penetration for the enzyme. To check that the reduction in the flux of so superoxide anion was not due to $\mathbf{1}$ in interaction with the outer leaflet of the plasmic membrane, but to intracellular 1, cells were washed using a chaotropic agent $(\mathrm{NaCl} 1 \mathrm{M})$ before the addition of the ferricytochrome $c$. As shown in figure S3, no difference was observed with and without this chaotropic

${ }_{55}$ shock. Overall, these results indicate unambiguously that intracellular $\mathbf{1}$ is able to reduce efficiently the flux in superoxide.

To quantify the activity of $\mathbf{1}$ in comparison with CuZnSOD, the activity of extracellular $\mathbf{1}$ was estimated and compared with 60 that of CuZnSOD. As previously, cells were activated (IFN $\gamma /$ LPS) and then incubated $1 \mathrm{~h}$ with PMA, ferricytochrome $c$ and with $1(10 \mu \mathrm{M}), \mathrm{MnCl}_{2}(10 \mu \mathrm{M})$ or $\mathrm{CuZnSOD}(100 \mathrm{U} / \mathrm{mL})$. The activity of $10 \mu \mathrm{M}$ of extracellular 1 was found close to that of $100 \mathrm{U} / \mathrm{mL} \mathrm{CuZnSOD,} \mathrm{significantly} \mathrm{higher} \mathrm{than} \mathrm{the} \mathrm{weak}$ ${ }_{65}$ activity of $\mathrm{MnCl}_{2}$ (see Supp. Mat. and figure S4).

ROS and RNS fluxes at the single-cell level. Amperometric analyses of ROS and RNS release from macrophages cells using ultramicroelectrodes were performed as previously described ${ }^{55-57}$ Experiments consist of positioning a platinized 70 carbon fiber ultramicroelectrode in the close vicinity $(\sim 100$ $\mathrm{nm})$ of a single isolated living cell using micromanipulators ("artificial synapse" configuration). In the present experiments, macrophages were pre-incubated for $24 \mathrm{~h}$ with IFN $\gamma / \mathrm{LPS}$ and Mn derivatives $\left(1\right.$ or $\mathrm{MnCl}_{2}$ ) at $10 \mu \mathrm{M}$ or without. The pre75 incubation medium was then removed, and a medium supplemented with PMA was added. The ROS/RNS release was then monitored at the single-cell level by amperometry at a constant potential as a function of time by applying a series of amperometric measurements at different potentials $(+300 \mathrm{mV}$, ${ }_{80}+450 \mathrm{mV},+650 \mathrm{mV}$, and $+850 \mathrm{mV}$ versus sodium-saturated calomel reference electrode (SSCE)) and integrated during one hour (see Figure S5). Averaging these individual responses over 30 cells allowed a statistically significant quantification of the four electroactive species $\left(\mathrm{H}_{2} \mathrm{O}_{2}, \mathrm{ONOO}^{-}, \mathrm{NO}\right.$, or $\left.\mathrm{NO}_{2}{ }^{-}\right)$ 85 fluxes (see Figure 3 and Supp. Mat., Table S1 and Figure S7). Cells pre-treated with 1 at $1 \mu \mathrm{M}$ or $\mathrm{MnCl}_{2}$ at $10 \mu \mathrm{M}$ did not exhibit any alteration of ROS/RNS release in comparison with conditions without any Mn-salt (see Supp. Mat., Figures S6, S8 and S9.).

${ }_{90}$ Extractions of the mean amount of $\mathrm{H}_{2} \mathrm{O}_{2}, \mathrm{ONOO}^{-}$, NO, and $\mathrm{NO}_{2}{ }^{-}$released over one hour by a single macrophage are summarized in Figure 3. The initial fluxes of $\mathrm{O}_{2}^{-}$and $\mathrm{NO}$ can be back-calculated (see Supp. Mat. and Table $\underline{\mathrm{S}} 1$ ) from the concentrations in $\mathrm{H}_{2} \mathrm{O}_{2}, \mathrm{ONOO}^{-}, \mathrm{NO}$, and $\mathrm{NO}_{2}{ }^{-}$in Figure 3 95 and Table S1. ${ }^{55-57}$ The weak differences, if any, in the initial fluxes recorded with and without preincubation with $\mathbf{1}$ indicate that incubated $\mathbf{1}$ does not inhibit the production of superoxide nor that of NO. However, the peroxynitrite amount released during the oxidative burst was drastically reduced (about one 100 fourth) in the case of cells pre-incubated with $1(10 \mu \mathrm{M})$ in 
comparison with control cells, while the amount of hydrogen peroxide was significantly but only slightly increased (about one and a half). In addition, the $\mathrm{NO}$ and $\mathrm{NO}_{2}^{-}$amounts detected directly were not significantly modified. Considering 5 the decomposition scheme of superoxide/nitric oxide occurring for macrophages activation (scheme 1), these observations are consistent with the SOD-activity of $\mathbf{1}$, previously evaluated in vitro $^{35}$, in an extracellular environment (see figure S4) or inside macrophages (see figure 2). Indeed, the SOD-mimic 1 10 accelerates the superoxide conversion into hydrogen peroxide (scheme 1 reaction (1)), which is a pathway in competition with the reaction between $\mathrm{NO}$ and $\mathrm{O}_{2}^{-}$(reaction (2)), and thus decreases the peroxynitrite amount detected at the electrode. Since the peroxynitrite anion arises only from superoxide/nitric 15 oxide reaction with a stoichiometry of 1 peroxynitrite per superoxide, and superoxide disproportionation provides $1 / 2$ $\mathrm{H}_{2} \mathrm{O}_{2}$ per superoxide, the overall peroxynitrite decrease should be twice that of $\mathrm{H}_{2} \mathrm{O}_{2}$ increase. In these experiments, the average decrease in peroxynitrite was evaluated to $2 \mathrm{fmol}$ 20 whereas the average increase in $\mathrm{H}_{2} \mathrm{O}_{2}$ was evaluated to 0.3 fmol, which is below the expected value ( $c a .1 \mathrm{fmol})$. This result points at a possible direct reaction of $\mathbf{1}$ with the peroxynitrite anion and/or with $\mathrm{H}_{2} \mathrm{O}_{2}$ (reaction (3)).

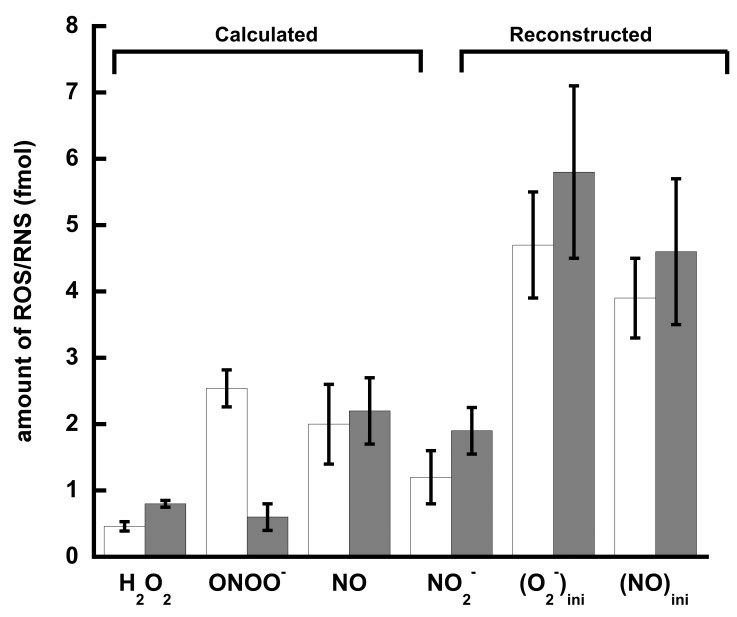

Figure 3. Mean amounts (fmol) of ROS/RNS species $\left(\mathrm{H}_{2} \mathrm{O}_{2}\right.$, ONOO$\mathrm{NO}$ and $\mathrm{NO}_{2}{ }^{-}$) measured per single cell over a $1 \mathrm{~h}$ period through electrochemical detection at four different potentials. Original fluxes (labelled "ini") can be reconstructed for superoxide and nitric oxide 30 (see Supp. Mat. for details). Single cell measurements were performed on RAW 264.7 macrophages activated by IFN- $\gamma /$ LPS - PMA and pretreated with (gray bar) or without (white bar) $10 \mu \mathrm{M}$ of 1 during $24 \mathrm{~h}$. The results correspond to 30 independent amperometric measurements per potential. Error bars represent SEM ( $\mathrm{n}=30$ cells). See Table $\mathrm{S} 1$ and 35 figure $\mathrm{S} 9$ for fluxes in the case of $\mathrm{MnCl}_{2}$.

Additional in vitro reactivity of 1 . To rationalize these observations, reactivity of $\mathbf{1}$ with $\mathrm{NO}, \mathrm{ONOO}^{-}$, and $\mathrm{H}_{2} \mathrm{O}_{2}$ were investigated in vitro. First, the reactivity of the Mn-complex 40 with NO was questioned using an NO-donor, namely, DEANONATE (see Supp. Mat.). Evolution of the expected NO absorbance $\left(\lambda_{\max }\right.$ at $\left.250 \mathrm{~nm}\right)$ decrease was monitored with or without 1 ( 1 eq.), showing that, under such experimental conditions, the intrinsic slow decomposition of NO was not ${ }_{45}$ affected by the presence of $\mathbf{1}$ (see figure S10). This result establishes the absence of reactivity of $\mathbf{1}$ with $\mathrm{NO}$, as expected from the single-cell fluxes determination. The reactivity of $\mathbf{1}$ with $\mathrm{ONOO}^{-}$was investigated in vitro at $\mathrm{pH}=10.6$. Indeed, $\mathrm{ONOO}^{-}$is intrinsically very unstable at acidic or physiological ${ }_{50} \mathrm{pH}(7.4)\left(\mathrm{t}_{1 / 2} \sim 0.5 \mathrm{~s}\right),{ }^{58}$ forbidding in vitro investigations at such a $\mathrm{pH}$. Conversely, the reactivity with 1 could be tested in very basic conditions, in which its decomposition in absence of target molecules is slowed down. ${ }^{59}$ As shown in figure S11, the peroxynitrite decomposition, monitored at $302 \mathrm{~nm}$, was found 55 to be faster in the presence of 1 ( 0.1 eq.), thus indicating a catalytic effect of $\mathbf{1}$, close that of a previously published NOdismutase Mn-complex (see supp. Mat). ${ }^{30}$ Although these strongly basic conditions are far from being physiological, this qualitative experiment indicates a possible reaction with 60 peroxynitrite and $\mathbf{1}$, whenever both species are present simultaneously in a same cellular compartment. Furthermore, the catalase activity, consisting of the catalysis of hydrogen peroxide dismutation, of $\mathbf{1}(20 \mu \mathrm{M})$ was assayed by monitoring the conversion of hydrogen peroxide $(50 \mathrm{mM})$ into dioxygen ${ }_{65}$ using a Clark-type electrode (see Supp. Mat.). ${ }^{16,60-62}$ The initial catalase rate for 1 was $69 \pm 17 \mu \mathrm{M} \mathrm{O}_{2}$ produced $/ \mathrm{min}$, while the maximal concentration in $\mathrm{O}_{2}$ was $67 \pm 10 \mu \mathrm{M}$, which is in the range of previously reported salen (EUK) complexes, known catalytic scavengers of $\mathrm{H}_{2} \mathrm{O}_{2}{ }^{16,}{ }^{160,62}$ The present results, with 70 disproportionation of 6.7 moles of $\mathrm{H}_{2} \mathrm{O}_{2}$ per mole of metal complex, is consistent with catalase activity. ${ }^{16,60,62}$

\section{Conclusion}

Macrophages are considered as relevant models for oxidative stress and for testing the antioxidant properties of SOD-mimics 75 in a cellular context. ${ }^{30}$ Amperometric measurements of ROS and RNS provide a complete picture of the reactivity of the SOD-mimic in biological conditions, with a direct evaluation of extracellular fluxes in $\mathrm{H}_{2} \mathrm{O}_{2}, \mathrm{ONOO}^{-}$, $\mathrm{NO}$ and $\mathrm{NO}_{2}{ }^{-}$, and a possible back calculation of initial fluxes/production of $\mathrm{O}_{2}^{-}$ 80 and NO. Complementary information was obtained from the ferricytochrome $c$ test, which measures the flux in superoxide in the extracellular medium. "Artificial synapse" amperometric measurements established that cells pre-treated with 1 showed a significantly reduced flux in superoxide without any 85 modification in the superoxide initial production. In addition, these measurements indicated that intracellular 1 did not modify the fluxes in $\mathrm{NO}$ nor in $\mathrm{NO}_{2}^{-}$, but significantly reduced the flux in $\mathrm{ONOO}^{-}$, with an increase in $\mathrm{H}_{2} \mathrm{O}_{2}$ weaker than what could have been expected in the case of a pure SOD 90 activity. These results suggested that, beyond its SOD-mimic activity, complex 1 can react with $\mathrm{ONOO}^{-}$and $\mathrm{H}_{2} \mathrm{O}_{2}$, that was evaluated in vitro.

Interestingly, intracellular 1 was found to be an efficient SODmimic, as expected from its design, ${ }^{32,35}$ and it was found to ${ }_{95}$ display attractive additional reactivity with the harmful ROS and $\mathrm{RNS} \mathrm{H}_{2} \mathrm{O}_{2}$ and $\mathrm{ONOO}^{-}$, without any reactivity with the beneficial NO. 1 is thus an interesting derivative for further test in cellular models of oxidative stress.

100 Abbreviations

DEANONOate $=$ diethylammonium $(\mathrm{Z})-1$ - $(N, N$-diethylamino $)$ diazen1-ium-1,2-diolate; DMEM = Dubelcco's modified Eagle medium; 
DMSO = dimethylsulfoxide; HEPES = 4-(2-hydroxyethyl)-1piperazineethanesulfonic acid IFN- $\gamma=$ interferon $-\gamma ; \mathrm{GSH}=$ glutathione; LPS $=$ Escherichia coli lipopolysaccharide O111:B4; MTT = 3-(4,5dimethylthiazol-2-yl)-2,5-diphenyltetrazolium bromide; NADPH = 5 reduced nicotinamide adenine dinucleotide phosphate; iNOS $=$ inductible NO-synthase; PMA $=$ Phorbol myristate acetate; RNS = reactive nitrogen species; $\mathrm{ROS}=$ reactive oxygen species; $\mathrm{SEM}=$ standard error of mean; $\mathrm{SCE}=\mathrm{KCl}$ saturated calomel electrode $(0.242 \mathrm{~V} / \mathrm{NHE}) ; \quad \mathrm{SSCE}=\mathrm{NaCl}$ saturated calomel electrode $10(0.236 \mathrm{~V} / \mathrm{NHE}) ; \mathrm{SOD}=$ superoxide dismutase

\section{Notes and references}

${ }^{a}$ Ecole Normale Supérieure, Département de chimie, 24, rue Lhomond, 75005 Paris, France, Fax: 33-144323858; e-mail: 15 clotilde.policar@ens.fr ${ }^{b}$ Université Pierre et Marie Curie Paris 6, 4, Place Jussieu, 75005 Paris, ${ }^{c}$ CNRS, UMR7203, ${ }^{d}$ CNRS, UMR8640, ${ }^{e}$ Institut de Chimie Moléculaire et des Matériaux d'Orsay, Université Paris-Sud 11, 91405 Orsay, France

\# ASB and CG have equally contributed to the work (first authors)

$\dagger$ Electronic Supplementary Information (ESI) available: 1. Chemicals, 2. Stability of the complex, 3. Cell-culture, 4. Cell-growth, 5. SODactivity evaluation in a cellular context using ferricytochrome $c$, effect of intracellular and extracellular 1, 6.Microelectrodes fabrication, 7.

25 Single-cells measurements, 8. In vitro activity of 1 with NO, 9. In vitro activity of 1 with $\mathrm{ONOO}^{-}, 10$. In vitro activity of 1 with $\mathrm{H}_{2} \mathrm{O}_{2}$. catalase effect. See DOI: 10.1039/b000000x/

Acknowledgement: ENS is gratefully acknowledged for ASB's and ${ }_{30}$ CG's fellowships and the ANR for VC's post-doc fellowship and financial support (projects METABACT and TAKE CARE)

1. B. Halliwell and J. M. C. Gutteridge, Free radicals in biology and medicine, Oxford University Press, New York, 1999.

35 2. J. M. McCord and M. A. Edeas, Biomedecine \& Pharmacotherapy, 2005, 59, 139-142.

3. S. Cuzzocrea, D. P. Riley, A. P. Caputi and D. Salvemini, Pharmaco Rev, 2001, 53, 135-159.

4. D. Salvemini, C. Muscoli, D. P. Riley and S. Cuzzocrea, Pulmonary

40 Pharmacology and Therapeutics, 2002, 15, 439-447.

5. I. Batinic-Haberle, S. Reboucas Julio and I. Spasojevic, Antioxydants and redox signaling, 2010, 13, 877-918.

6. J. R. Anacona, M. Azocar, O. Nusetti and C. Rodriguez-Barbarin, Transition Metal Chemistry, 2003, 28, 24-28.

45 7. F. Bellot, R. Hardré, G. Pelosi, M. Thérisod and C. Policar, Chem. Commun., 2005, 5414-5417.

8. D. P. Riley, Chem. Rev., 1999, 99, 2573-2587.

9. O. Iranzo, Bioorganic Chemistry, 2011, 39, 73-87.

10. W. Munroe, C. Kingsley, A. Durazo, E. B. Gralla, J. A. Imlay, C.

50 Srinivasan and J. S. Valentine, Journal of Inorganic Biochemistry 2007, 101 1875-1882.

11. B. Gauter-Fleckenstein, K. Fleckenstein, K. Owzar, C. Jiang, I. Batinic-Haberle and Z. Vujaskovic, Free Radic Biol Med, 2008, 44, 982989.

55 12. B. Gauter-Fleckenstein, K. Fleckenstein, K. Owzar, C. Jiang, J. S. Reboucas, I. Batinic-Haberle and Z. Vujaskovic, Free Radical Biology \& Medicine, 2010, 48, 1034-1043.

13. R. D. Pearlstein, Y. Higuchi, M. Moldovan, K. Johnson, S. Fukuda, D. S. Gridley, J. D. Crapo, D. S. Warner and J. M. Slater, International 60 Journal of Radiation Biology, 2010, 86, 145-163.

14. J. Alexandre, C. Nicco, C. Chereau, A. Laurent, B. Weill, F. Goldwasser and F. Batteux, J Natl Cancer Inst, 2006, 98, 236-244.

15. S. Bedda, A. Laurent, F. Conti, C. Chereau, A. Tran, J. Tran-Van Nhieu, P. Jaffray, O. Soubrane, C. Goulvestre, Y. Calmus, B. Weill and F. 65 Batteux, Journal of hepatology, 2003, 39, 765-772.
16. S. R. Doctrow, K. Huffman, C. B. Marcus, G. Tocco, E. Malfroy, C. A. Adinolfi, H. Kruk, K. Baker, N. Lazarowych, J. Mascarenhas and B. Malfroy, J. Med. Chem., 2002, 45, 4549-4558.

17. H. Sheng, J. J. Enghild, R. Bowler, M. Patel, I. Batinic-Haberle, C. L. 70 Calvi, B. J. Day, R. D. Pearlstein, J. D. Crapo and D. S. Warner, Free Radical Biology \& Medicine, 2002, 33, 947-961.

18. H. Brurok, J. H. Ardenkjaer-Larsen, G. Hansson, S. Skarra, K. Berg, J. O. G. Karlsson, I. Laursen and P. Jynge, Biochem. Biophys. Res. Commun., 2006, 254, 768-772.

75 19. E. Masini, S. Cuzzocrea, E. Mazzon, C. Marzocca, P. F. Mannaioni and D. Salvemini, British Journal of Pharmacology, 2002, 136, 905-917. 20. Y. Rong, S. R. Doctrow, G. Tocco and M. Baudry, P.N.A.S., 1999, 96, 9897-9902.

21. O. Vajragupta, P. Boonchoong, Y. Sumanot, Y. Watanabe, Y.

80 Wongkrajang and N. Kammasud, Bio. Med. Chem, 2003, 11, 23292337.

22. M. C. McDonald, R. d'Emmanuele di Villa Bianca, N. S. Wayman, A. Pinto, M. A. Sharpe, S. Cuzzocrea, P. K. Chatterjee and C. Thiemermann, Eur. J. Pharmacol., 2003, 466, 181-189.

85 23. I. Batinic-Haberle and L. T. Benov, Free Radical Research, 2008, 42, 618-624.

24. E. Masini, D. DBani, A. Vannacci, S. Pierpaoli, P. F. Mannaioni, S. A. A. Comhair, W. Xu, C. Muscoli, S. C. Erzurum and D. Salvemini, Free Radical Biology \& Medicine, 2005, 39, 520-531.

90 25. A. Okado-Matsumoto, I. Batinic-Haberle and I. Fridovich, Free Radical Biology \& Medicine, 2004, 37, 401-410.

26. I. Spasojevic, I. Batinic-Haberle, R. D. Stevens, P. Hambright, A. N. Thorpe, J. Grodkowski, P. Neta and I. Fridovich, Inorg. Chem., 2001, 40, 726-739.

95 27. M. N. Patel, 2003, 2, 219-222.

28. B. J. Moeller, I. Batinic-Haberle, I. Spasojevic, Z. N. Rabbani, M. S. Anscher, Z. Vujaskovic and M. W. Dewhirst, International Journal of Radiation Oncology, Biology, Physics, 2005, 63, 545-552.

29. J. M. Pollard, J. S. Reboucas, A. Durazo, I. Kos, F. Fike, M. Panni, E.

100 Butler Gralla, J. S. Valentine, I. Batinic-Haberle and R. A. Gatti, Free Radic Biol Med, 2009, 47, 250-260.

30. M. R. Filipovic, A. C. W. Koh, S. Arbault, V. Niketic, A. Debus, U. Schleicher, C. Bogdan, M. Guille, F. Lemaitre, C. Amatore and I. Ivanovic-Burmazovic, Angew. Chem., Int. ed. Engl., 2010, 49, 42281054232.

31. M. M. Ndengele, C. Muscoli, Z. Q. Wang, T. M. Doyle, G. G. Matuschak and D. Salvemini, Shock, 2005, 23, 186-195.

32. I. L. Jackson, I. Batinic-Haberle, P. Sonveaux, M. W. Dewhirst and Z. Vujaskovic, Int. J. Hyperthermia, 2006, 22, 263-273.

110 33. I. L. Jackson, L. Chen, I. Batinic-Haberle and Z. Vujaskovic, Free Radical Research, 2007, 41, 8-14.

34. F. Matemadombo, M. Durmus, V. Escriou, S. Griveau, D. Scherman, F. Bedioui and T. Nyokong, Curr. Anal. Chem., 2009, 5, 330-338.

35. F. Cisnetti, A. S. Lefevre, R. Guillot, F. Lambert, G. Blain, E.

115 Anxolabéhère-Mallart and C. Policar, Eur. J. Inorg. Chem., 2007, 44724480.

36. F. Cisnetti, G. Pelosi and C. Policar, Inorg. Chim. Acta, 2007, 360, 557-562.

37. S. Durot, F. Lambert, J.-P. Renault and C. Policar, Eur. J. Inorg. 120 Chem., 2005, 2789-2793.

38. S. Durot, C. Policar, F. Cisnetti, F. Lambert, J.-P. Renault, G. Pelosi, G. Blain, H. Korri-Youssoufi and J.-P. Mahy, Eur. J. Inorg. Chem., 2005, 3513-3523.

39. S. Groni, G. Blain, R. Guillot, C. Policar and E. Anxolabéhère125 Mallart, Inorg. Chem., 2007, 46, 1951-1953.

40. C. Policar, S. Durot, F. Lambert, M. Cesario, F. Ramiandrasoa and I. Morgenstern-Badarau, Eur. J. Inorg. Chem., 2001, 1807-1818.

41. C. Policar, F. Lambert, M. Cesario and I. Morgenstern-Bararau, Eur. J. Inorg. Chem., 1999, 2201-2207.

130 42. I. Batinic-Haberle, I. Spasojevic, R. D. Stevens, P. Hambright, P. Neta, A. Okado-Matsumoto and I. Fridovich, J. Chem. Soc., Dalton Trans., 2004, 1696-1702. 
43. W. C. J. Barrette, D. T. Sawyer, J. A. Fee and K. Asada, Biochemistry, 1983, 22, 624-627.

44. $\mathrm{k}_{\mathrm{McCF}}$ is a kinetic constant directly derived from the McCord and Fridovich test, which is a conventional evaluation of the SOD-like 5 activity. It corresponds to $\mathrm{k}_{\mathrm{cat}}$ measured by pulse radiolysis ${ }^{26,37}$ and is defined in $\operatorname{ref}^{38}$.

45. C. Bogdan, Nat. Immunol., 2001, 2, 907-916.

46. C. Bogdan, M. Röllinghoff and A. Diefenbach, Curr. Opin. Immunol. , 2000, 12, 64-76.

10 47. After being stimulated as described here, macrophages act through a process named phagocytosis. Briefly, the macrophage first extends its membrane towards the target and subsequently traps it within a membrane-bound vacuole (phagosome). The macrophage digests and destroys the internalized target by releasing in situ a

15 mixture of ROS/RNS species. During this process, significant ROS/RNS amounts are fastly produced by the enzymes NADPH oxidase and iNOS. Once degraded, the phagosome contents are then emptied into the extracellular medium. By comparison, since the ultramicroelectrode is localized in the close vicinity of the 20 macrophage, the typically weak and broad peaks recorded through amperometry are due to the detection of one or more types of ROS/RNS, that are quasi-continuously generated by phagosomes fusion with the cell external membrane. In that way, the ROS/RNS species, though endogenously produced, are eventually detected

25 after their release in the extracellular fluid. On the other hand 1 is removed from the cells environments during measurements so any effect detected due to cells pre-incubation with 1 cannot be ascribed to the release event but must necessarily be related to its action within the phagosomes.

30 48. C. Amatore, S. Arbault, M. Guille and F. Lemaitre, Chem. Rev., 2008, 108, 2585-2621 and references therein.

49. J. D. Burton, Methods Mol. Med., 2005, 110, 69-78.

50. M. N. Alvarez and M. Trujillo, Radi Methods Enzymol., 1986, 359, 353-366.

35 51. P. Bellavite, Free Radical Biology \& Medicine, 1988, 4, 225-261.

52. F. Rossi, Biochim. Biophys. Acta, Rev. Bioenerg., 1986, 853, 65-89.

53. E. Njamkepo, F. Pinot, D. Franc, N. Guiso, B. S. Polla and M. Bachelet, Journal of Cellular Physiology, 2000, 183, 91-99.

54. K. Barnese, E. B. Gralla, D. E. Cabelli and J. S. Valentine, J. Am. 40 Chem. Soc., 2008, 130, 4604-4606.

55. C. Amatore, S. Arbault, C. Bouton, K. Coffi, H. Ghandour and Y. H. Tong, ChemBioChem, 2006, 7, 653-661.

56. C. Amatore, S. Arbault, C. Bouton, J. C. Drapier, H. Ghandour and A. Koh, ChemBioChem, 2008, 9, 1472-1480.

45 57. C. Amatore, S. Arbault, D. Bruce, P. de Oliveira, M. Erard and M. Vuillaume, Faraday Discuss., 2000, 116, 319-333.

58. G. Ferrer-Sueta and G. Radi, ACS Chem. Biol., 2009, 4, 161-177 and references cited therein.

59. J.-H. M. Tsai, J. G. Harrison, J. C. Martin, T. P. Hamilton, M. avn der

50 Woerd, M. J. Jablonsky and J. S. Beckman, J. Am. Chem. Soc., 1994, 116, 4115-4116.

60. K. Baker, C. B. Marcus, C. B. Huffman, H. Kruk, B. Malfroy and S. R. Doctrow, J. Pharmacol. Exp. Ther. , 1998, 284, 215-221.

61. D. Moreno, V. Daier, C. Palopolo, J.-P. Tuchagues and S. Signorella, 55 J. Inorg. Biochem., 2010, 104, 496-502.

62. W. Park and D. Lim, Biorganic and medicinal chemistry letters, 2009, 19, 614-617. 